\title{
Asma pada Anak
}

\author{
Arwin AP Akib
}

\begin{abstract}
Asma pada anak mempunyai berbagai aspek khusus yang umumnya berkaitan dengan proses tumbuh dan kembang seorang anak, baik pada masa bayi, balita, maupun anak besar. Peran atopi pada asma anak sangat besar dan merupakan faktor terpenting yang harus dipertimbangkan dengan baik untuk diagnosis dan upaya penatalaksanaan. Mekanisme sensitisasi terhadap alergen serta perkembangan perjalanan alamiah penyakit alergi dapat memberi peluang untuk mengubah dan mencegah terjadinya asma melalui kontrol lingkungan dan pengobatan pada seorang anak. Pendidikan pada pasien dan keluarga merupakan unsur penting penatalaksanaan asma pada anak yang bertujuan untuk meminimalkan morbiditas fisis dan psikis serta mencegah disabilitas. Upaya pengobatan asma anak tidak dapat dipisahkan dari pemberian kortikosteroid yang merupakan anti-inflamasi terpilih untuk semua jenis dan tingkatan asma. Pemberian kortikosteroid topikal melalui inhalasi memberikan hasil sangat baik untuk mengontrol asma tanpa pengaruh buruk, walaupun pada anak kecil tidak begitu mudah untuk dilakukan sehingga masih memerlukan alat bantu inhalasi.
\end{abstract}

Kata kunci: reaksi inflamasi, allergic march, mengi, relievers controllers

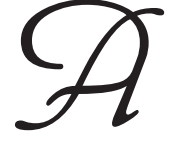

sma merupakan penyakit kronik tersering pada anak dan masih tetap merupakan masalah bagi pasien, keluarga, dan bahkan para klinisi dan peneliti asma. Mengacu pada data epidemiologi Amerika Serikat pada saat ini diperkirakan terdapat 4-7\% (4,8 juta anak) dari seluruh populasi asma. Selain karena jumlahnya yang banyak, pasien asma anak dapat terdiri dari bayi, anak, dan remaja, serta mempunyai permasalahan masing-masing dengan implikasi khusus pada penatalaksanaannya.

Pengetahuan dasar tentang masalah sensitisasi alergi dan inflamasi khususnya, telah banyak mengubah sikap kita terhadap pengobatan asma anak, terutama tentang peran anti-inflamasi sebagai salah satu dasar pengobatan asma anak. Oleh karena itu pengertian yang lebih baik tentang peran faktor genetik, sensitisasi dini oleh alergen dan polutan, infeksi virus, serta masalah lingkungan sosioekonomi dan psikologi anak dengan

Alamat Korespondensi:

Dr. Arwin A.P. Akib, Sp.A(K)

Subbagian Alergi-Imunologi Bagian Ilmu Kesehatan Anak FKUI-RSCM. Jl. Salemba no. 6 Jakarta 10430.

Telepon: 021-3161144 Fax.: 021-3907743. asma diharapkan dapat membawa perbaikan dalam penatalaksanaan asma.

\section{Patogenesis}

\section{Reaksi inflamasi}

Patogenesis asma dapat diterangkan secara sederhana sebagai bronkokonstriksi akibat proses inflamasi yang terjadi terus-menerus pada saluran napas. Karena itu pemberian anti-inflamasi memegang peranan penting pada pengobatan dan kontrol asma. Terlihat bahwa setelah pemberian inhalasi kortikosteroid akan terjadi penurunan bermakna sel inflamasi dan pertanda permukaan sel pada sediaan bilas dan biopsi bronkoalveolar. Pemberian bronkodilator saja tidak dapat mengatasi reaksi inflamasi dengan baik.

Pada tingkat sel tampak bahwa setelah terjadi pajanan alergen serta rangsang infeksi maka sel mast, limfosit, dan makrofag akan melepas faktor kemotaktik yang menimbulkan migrasi eosinofil dan sel radang lain. Pada tingkat molekul terjadi pelepasan berbagai mediator serta ekspresi serangkaian reseptor permukaan 
oleh sel yang saling bekerjasama tersebut yang akan membentuk jalinan reaksi inflamasi. Pada orkestrasi proses inflamasi ini sangat besar pengaruh sel $\mathrm{Th}_{2}$ sebagai regulator penghasil sitokin yang dapat memacu pertumbuhan dan maturasi sel inflamasi alergi. Pada tingkat jaringan akan tampak kerusakan epitel serta sebukan sel inflamasi sampai submukosa bronkus, dan mungkin terjadi rekonstruksi mukosa oleh jaringan ikat serta hipertrofi otot polos.

\section{Sensitisasi}

Berbagai penelitian asma pada anak memperlihatkan adanya suatu pola hubungan antara proses sensitisasi alergi dengan perkembangan dan perjalanan penyakit alergi yang dikenal sebagai allergic march (perjalanan alamiah penyakit alergi). Secara klinis allergic march terlihat berawal sebagai alergi saluran cerna (diare alergi susu sapi) yang akan berkembang menjadi alergi kulit (dermatitis atopi) dan kemudian alergi saluran napas (asma bronkial, rinitis alergi).

Suatu penelitian memperlihatkan bahwa kelompok anak dengan gejala mengi pada usia kurang dari 3 tahun, yang menetap sampai usia 6 tahun, mempunyai predisposisi ibu asma, dermatitis atopi, rinitis alergi, dan peningkatan kadar lgE, dibandingkan dengan kelompok anak dengan mengi yang tidak menetap. Laporan tersebut juga menyatakan bahwa anak mengi yang akan berkembang menjadi asma terbukti mempunyai kemampuan untuk membentuk respons $\operatorname{lgE}$ serta respons eosinofil pada uji provokasi berbagai stimuli. Proses sensitisasi diperkirakan telah terjadi sejak awal masa kehidupan, secara bertahap mulai dari rangsang alergen makanan dan infeksi virus, sampai kemudian rangsang aeroalergen. Proses tersebut akan mempengaruhi modul respons imun yang akan lebih cenderung ke arah aktivitas $\mathrm{Th}_{2}$.

Kecenderungan aktivitas $\mathrm{Th}_{2}$ akan menurunkan produk IL-2 dan IFN- $\gamma$ oleh Th. $\mathrm{T}_{2}$. Terbukti bahwa anak dengan respons IFN- $\gamma$ rendah pada masa awal kehidupannya akan lebih tersensitisasi oleh aeroalergen dan menderita asma pada usia 6 tahun dibandingkan dengan anak dengan respon IFN- $\gamma$ normal.

\section{Diagnosis}

Masalah penting pada morbiditas asma adalah kemampuan untuk menegakkan diagnosis, dan seperti telah kita ketahui bahwa diagnosis asma pada anak tidak selalu mudah untuk ditegakkan. Beberapa kriteria diagnosis untuk itu selalu mempunyai berbagai kelemahan, tetapi umumnya disepakati bahwa hiper reaktivitas bronkus tetap merupakan bukti objektif yang perlu untuk diagnosis asma, termasuk untuk asma pada anak.

Gejala klinis utama asma anak pada umumnya adalah mengi berulang dan sesak napas, tetapi pada anak tidak jarang batuk kronik dapat merupakan satusatunya gejala klinis yang ditemukan. Biasanya batuk kronik itu berhubungan dengan infeksi saluran napas atas. Selain itu harus dipikirkan pula kemungkinan asma pada anak bila terdapat penurunan toleransi terhadap aktivitas fisik atau gejala batuk malam hari.

\section{Mengi pada bayi}

Sebagian besar manifestasi akan muncul sebelum usia 6 tahun dan kebanyakan gejala awal sudah ditemukan pada masa bayi, berupa mengi berulang atau tanpa batuk yang berhubungan dengan infeksi virus. Hubungan antara mengi semasa bayi dengan kejadian asma pada masa kehidupan selanjutnya telah banyak dibahas, para peneliti umumnya melaporkan bahwa hanya sebagian kecil saja (3-10\%) dari kelompok bayi mengi yang berhubungan dengan infeksi virus tersebut akan memperlihatkan progresivitas klinis menjadi asma bronkial.

Infeksi virus semasa bayi yang menimbulkan bronkiolitis dengan gejala mengi terutama disebabkan oleh virus sinsitial respiratori (RSV), virus parainfluenza, dan adenovirus. Kecenderungan bayi mengi untuk menjadi asma sangat ditentukan oleh faktor genetik atopi. Sebagian besar bayi tersebut jelas mempunyai riwayat keluarga atopi serta menunjukkan positivitas $\lg \mathrm{E}$ anti-RSV serum, dibandingkan dengan bayi mengi yang tidak menjadi asma.

Kemampuan bayi untuk membentuk $\lg E$ anti RSV ini diyakini sebagai status sensitisasi terhadap alergen secara umum. Jadi bayi mengi dengan ibu atopi yang mengandung lgE anti-RSV tersebut sudah dalam keadaan tersensitisasi, dan hal ini merupakan faktor risiko terjadinya asma. Sejalan dengan hal itu maka banyak peneliti telah melaporkan positivitas $\lg E$ spesifik terhadap berbagai alergen (susu, kacang, makanan laut, debu rumah, serbuk sari bunga) pada bayi merupakan faktor risiko dan prediktor untuk terjadinya asma. Para peneliti tersebut juga menyatakan semakin dini terjadi 
sensitisasi maka risiko untuk menjadi asma menetap juga semakin besar. Dengan demikian maka tidak begitu penting hubungan antara saat timbul mengi pada bayi dengan besarnya risiko terjadinya asma, karena yang menentukan sebetulnya adalah seberapa dini tejadi sensitisasi alergen pada bayi mengi tersebut. Penelitian umum bayi mengi memperlihatkan bahwa kejadian asma akan lebih kerap pada bayi yang mulai mengi pada usia lebih besar, berbeda dengan perkiraan sebelumnya bahwa semakin muda timbulnya mengi maka risiko untuk kejadian asma semakin besar.

\section{Atopi}

Sebagian sangat besar asma pada anak mempunyai dasar atopi, dengan alergen merupakan pencetus utama serangan asma. Diperkirakan bahwa sampai $90 \%$ anak pasien asma mempunyai alergi pada saluran napas, terutama terhadap alergen dalam rumah (indoor allergen) seperti tungau debu rumah, alternaria, kecoak, dan bulu kucing.

Telah disebutkan sebelumnya bahwa sebagian besar pasien asma berasal dari keluarga atopi, dan kandungan IgE spesifik pada seorang bayi dapat menjadi prediktor untuk terjadinya asma kelak di kemudian hari. Karena itu sangat penting untuk menelusuri dan membuktikan faktor atopi sebagai pendekatan diagnosis klinis pada anak dengan gejala klinis yang sesuai dengan asma bronkial. Riwayat atopi dalam keluarga, riwayat penyakit atopi sebelumnya pada pasien, petanda atopi fisis pada anak, petanda laboratorium untuk alergi, dan bila diperlukan uji eliminasi dan provokasi, dapat menunjang diagnosis asma pada anak tersebut.

\section{Tata laksana}

Pada masa anak terjadi proses tumbuh- kembang fisis, faal, imunologi, dan perilaku yang memberi peluang sangat besar bagi kita untuk melakukan upaya pencegahan, kontrol, self-management, dan pengobatan asma. Walaupun medikamentosa selalu merupakan unsur penting pengobatan asma anak, harus tetap diingat bahwa hal tersebut hanyalah merupakan salah satu dari berbagai komponen utama penatalaksanaan asma. Penatalaksanaan asma yang baik harus disokong oleh pengertian tentang peran genetik, alergen, polutan, infeksi virus, serta lingkungan sosioekonomi dan psikologis pasien beserta keluarga.
Pendidikan dan penjelasan tentang asma pada pasien dan keluarga merupakan unsur penting penatalaksanaan asma pada anak. Perlu penjelasan sederhana tentang proses penyakit, faktor risiko, penghindaran pencetus, manfaat dan cara kontrol lingkungan, cara mengatasi serangan akut, pemakaian obat dengan benar, serta hal lain yang semuanya bertujuan untuk meminimalkan morbiditas fisis dan psikis serta mencegah disabilitas.

Bila ditangani dengan baik maka pasien asma dapat memperoleh kualitas hidup yang sangat mendekati anak normal, dengan fungsi paru normal pada usia dewasa kelak walaupun tetap menunjukkan saluran napas yang hiperresponsif.

\section{Pencegahan}

Upaya pencegahan asma anak mencakup pencegahan dini sensitisasi terhadap alergen sejak masa fetus, pencegahan manifestasi asma bronkial pada pasien penyakit atopi yang belum menderita asma, serta pencegahan serangan dan eksaserbasi asma.

Kontrol lingkungan merupakan upaya pencegahan untuk menghindari pajanan alergen dan polutan, baik untuk mencegah sensitisasi maupun penghindaran pencetus. Para peneliti umumnya menyatakan bahwa alergen utama yang harus dihindari adalah tungau debu rumah, kecoak, bulu hewan peliharaan terutama kucing, spora jamur, dan serbuk sari bunga. Polutan harus dihindari adalah asap tembakau sehingga mutlak dilarang merokok dalam rumah. Polutan yang telah diidentifikasi berhubungan dengan eksaserbasi asma adalah asap kendaraan, kayu bakar, ozon, dan $\mathrm{SO}_{2}$. Penghindaran maksimal harus dilakukan di tempat anak biasa berada, terutama kamar tidur dan tempat bermain sehari-hari. Untuk Indonesia, walaupun belum ada data yang menyokong, agaknya kita harus menghindari obat nyamuk dan asap lampu minyak.

Beberapa klinik telah melakukan upaya pencegahan sensitisasi terhadap fetus dan bayi, antara lain dengan memberikan diet hipo dan non alergenik serta penghindaran asap rokok. Walaupun secara teoritis pemberian diet hipoalergenik pada masa trimester ketiga kehamilan sangat menarik, ternyata bukti klinis penelitian tersebut tidaklah menggembirakan. Tidak terlihat perbedaan kejadian penyakit alergi pada umur 5 tahun antara kelompok perlakuan dan kelola. Hasil lebih baik justru akan terlihat pada bayi yang mendapat 
ASI dari ibu dengan diet hipoalergenik pada masa laktasi. Sebaliknya terbukti bahwa ibu perokok akan membahayakan perkembangan paru bayi baik dilakukan pada masa sebelum maupun setelah kelahiran, yang berpengaruh terhadap peningkatan risiko terjadinya mengi dan infeksi virus serta asma kronik anak.

Berdasarkan pengetahuan dasar tentang proses sensitisasi dan allergic march maka upaya pencegahan asma dilakukan juga dengan mencegah dan menghambat perjalanan alamiah penyakit alergi. Upaya tersebut antara lain adalah dengan mencegah timbulnya suatu penyakit alergi (asma) pada anak yang telah tersensitisasi. Suatu uji klinis multisenter ETAC (early treatment of the atopic child) telah menunjukkan manfaat setirizin untuk menghambat timbulnya asma pada anak kecil penderita dermatitis atopi yang sudah tersensitisasi terhadap alergen tertentu tetapi belum menderita asma.

Untuk anak yang sudah menderita asma dilakukan pengobatan pencegahan dan kontrol asma yang bertujuan untuk mencegah kekambuhan, atau menurunkan kekerapan serta derajat serangan asma, dengan pemberian sodium kromolin, ketotifen, inhibitor dan antagonis leukotrien, serta kortikosteroid.

Sodium kromolin sulit diaplikasi pada anak kecil, sedangkan inhibitor serta antagonis leukotrien baru dianjurkan untuk anak besar ( $>12$ tahun) saja. Ketotifen sejauh ini memberikan efek profilaksis terutama untuk asma ringan. Berbagai jenis antihistamin generasi baru mungkin dapat bermanfaat pula sebagai pencegah asma tetapi uji klinis yang memadai untuk itu belum ada.

Sejauh ini kortikosteroid merupakan antiinflamasi terpilih yang paling efektif untuk pencegahan asma. Pemberian kortikosteroid inhalasi dapat mengontrol asma kronik dengan baik, walaupun pada anak kecil relatif lebih sulit dilakukan sehingga membutuhkan alat bantu inhalasi.

\section{Pengobatan Asma}

Pengobatan asma pada dasarnya bertujuan untuk mendapatkan dan menjaga status aktivitas anak normal dan faal paru normal, mencegah timbulnya asma kronik, serta mencegah pengaruh buruk tindakan pengobatan. Secara umum obat asma dapat dibagi menjadi dua kelompok, yaitu obat pelega (relievers) dan obat pengontrol (controllers).
Obat pelega asma bertujuan untuk melegakan saluran napas dan menghilangkan serangan serta eksaserbasi akut dengan pemberian bronkodilator. Bronkodilator yang banyak dipakai saat ini adalah ${ }_{2}{ }^{-}$ agonis, selain xantin dan antikolinergik. Obat pengontrol asma bertujuan menjaga dan mengontro asma persisten dengan mencegah kekambuhan. Obat pengontrol asma yang banyak dipergunakan adalah kortikosteroid, selain anti-inflamasi lain seperti sodium kromolin, nedokromil, inhibitor dan antagonis leukotrien, serta berbagai antihistamin generasi baru.

Obat $\beta_{2}$-agonis bermanfaat untuk dipakai sebagai terapi intermiten asma episodik, sebagai tambahan terapi intermiten, atau terapi rutin penunjang anti-inflamasi pada asma relaps berulang atau kronis, sebelum aktifitas fisik untuk menghambat exercise induced asthma, dan untuk penolong asma akut. Obat ini tersedia dalam bentuk oral, atau inhalasi yang efektif dilakukan dengan inhaler dosis terukur, rotohaler, atau nebuliser.

Teofilin merupakan preparat metil-xantin yang pada masanya sangat populer untuk terapi rumatan asma kronik ringan, dan sebagai penunjang pengobatan asma kronik berat. Walaupun saat ini masih banyak dipakai, teofilin tidak begitu menarik lagi setelah pengobatan anti-inflamasi untuk asma lebih terfokus kepada kortikosteroid. Selama ini efek anti-inflamasi teofilin memang masih sering dipertanyakan. Selain itu metabolisme teofilin diketahui akan terganggu dalam keadaan demam oleh penyakit tertentu, seperti influenza, atau oleh obat seperti eritromisin, simetidin, dan siprofloksasin. Pada anak, teofilin juga diketahui dapat mempengaruhi prestasi sekolah sehingga tidak dianjurkan untuk diberikan pada anak dengan gangguan psikologis atau gangguan belajar.

Obat antikolinergik selain bersifat bronkodilator juga akan mengurangi hipersekresi mukus dan mengatasi iritabilitas reseptor batuk. Obat ini tersedia dalam bentuk inhalasi dan nebulasi, terbukti efektif untuk asma akut bila diberikan bersama $\mathrm{b}_{2}$-agonis.

Seperti telah disebutkan maka pengontrol asma merupakan pengobatan yang efektif untuk pencegahan asma dan dipergunakan untuk semua tingkatan asma. Kortikosteroid merupakan obat terpilih dan sangat efektif, baik dalam bentuk parenteral dan oral untuk jangka pendek, maupun bentuk inhalasi yang terutama dicadangkan untuk pemakaian jangka panjang. Sejak mula pertama dipergunakan lebih dari 20 tahun lalu terlihat bahwa kortikosteroid inhalasi jelas memberi efek terapi sangat baik untuk asma ringan, sedang, dan 
berat; baik untuk pengobatan jangka pendek maupun jangka panjang. Sejauh ini tidak ditemukan efek buruk yang berarti bila diberi dengan dosis yang dianjurkan.

\section{Daftar Pustaka}

1. Gern JE, Lemanske Jr RF. Pediatric allergy: can it be prevented? Immunol Allergy Clin North Amer 1999; 19:233-52.

2. Wiesch DG, Meyers DA, Bleecker ER. Genetics of asthma. J Allergy Clin Immunol 1999; 104:895-901.

3. Postma DS, Meijer GG, Koppelman GH. Definition of asthma: possible approaches in genetic studies. Clin Exp Allergy 1998; 28suppl.1:S62-4.

4. Maartinez FD. Asthma phenotypes. Wheezy infants and wheezy children. Immunol Allergy Clin North Amer $1998 ; 18: 25-33$.
5. Sherrill DL, Stein R, Halonen M, Holberg CJ, Wright A, Martinez FD. Total serum $\operatorname{lgE}$ and its association with asthma symptoms and allergic sensitization among children. J Allergy Clin Immunol 1999; 104:28-36.

6. Saphiro GG. Management of pediatric asthma. Care by the specialist. Immunol Allergy Clin North Am 1998; 18:1-23.

7. Bergmann RL, Edenharter G, Bergmann KE, Lau S, Wahn U, Multicenter allergy study research group. Socioeconomic status is a risk factor for allergy in parentas but not in their children. Clin Exp Allergy 2000; 30:1740-5.

8. ETAC Study Group, Wahn U. Allergic factors associated with the development of asthma and the influence of centirizine in a doubleblind, randomized, placebocontrolled trial: first result of ETAC. Pediatr Allergy Immunol 1998; 9:116-24.

9. Pedersen S. Safety and efficacy of inhaled corticosteroid in children. Immunol Allergy Clin North Am 1999; 19:753-81. 